\title{
Representation of Spatial Data Modeling Results Measles Diseases, Case Study in East Java Province
}

\section{Representasi Hasil Pemodelan Data Spasial Penyakit Campak, Studi Kasus di Provinsi Jawa Timur}

\author{
Anik Vega Vitianingsih", Achmad Choiron², Dwi Cahyono3, \\ Suyanto $^{4}$
}

Paper Type:

Teknik Informatika, Universitas Dr.Soetomo Surabaya ${ }^{1,2,3}$

Research Paper

Fakultas Ekonomi dan Bisnis, Universitas Dr. Soetomo Surabaya ${ }^{4}$

\begin{abstract}
Background of the study: Measles is a major cause of child death caused by a lack of immunization when a child is a baby.

Purpose: The discussion in this paper aims to describe the results of the analysis of the spatial data modeling of measles, knowing the percentage distribution of measles-prone areas, each district based on coverage on immunization status with good, average, fair and poor classification categories. The classification results include areas with good, average, fair, and poor immunization coverage status categories.

Method: The method used i.e. with to requirement gathering information data from the East Java health profile book in 2011-2016 for the measles attribute, a literature study to describe the parameter requirements based on the coverage of immunization status (infant immunization status, PD3I, epidemic, and nutritional status), and selection of artificial intelligent (AI) system methods that are in accordance with data behavior for the spatial data modeling process in the formulation of alternative preference values with a decision-making system that involves multi-criteria parameters (multiple attributes decision-making/MADM) with Simple Additive Weighting (SAW) method.

Findings: The alternative preference value $\mathrm{Vi}$ in the spatial data modeling process with the SAW method can be used as a mathematical model for the same data series behavior.

Conclusion: The results of the representation in the modeling of spatial data and this attribute data can be used as a reference for planning in the development of health care centers in areas with poor immunization status categories.
\end{abstract}

Keywords: spatial analysis, spatial data modeling, measles, MADM. 


\begin{abstract}
Abstrak
Latar belakang: Penyakit campak menjadi penyebab utama kematian anak yang disebabkan oleh faktor kurangnya imunisasi saat anak masih bayi.

Tujuan: Pembahasan dalam makalah ini bertujuan untuk memberikan paparan dari representasi hasil analisa pada pemodelan data spasial penyakit campak, mengetahui prosentase sebaran wilayah rawan penyakit campak per Kabupaten dimasing-masing Wilayah Kecamatan berdasarkan cakupan status imunisasi dengan kategori klasifikasi baik, cukup, kurang dan buruk.

Metode Penelitian: Metode yang digunakan yaitu dengan mengumpulkan kebutuhan informasi yang didapat dari buku profil kesehatan Jawa Timur tahun 2011-2016 untuk atribut penyakit campak, studi literatur untuk menguraikan kebutuhan parameter berdasarkan cakupan status imunisasi yang meliputi status imunisasi bayi, PD3I, epidemic, dan status gizi, dan pemilihan metode sistem cerdas yang sesuai dengan perilaku data untuk proses pemodelan data spasial dalam perumusan nilai preferensi alternatif dengan sistem pengambilan keputusan yang melibatkan multi-kriteria parameter (multiple attribute decision making/MADM) dengan metode Simple Additive Weighting (SAW).

Temuan: Nilai prefensi alternatif $V_{i}$ pada proses pemodelan data spasial dengan metode SAW dapat dijadikan sebagai model matematis untuk perilaku data series yang sama.

Kesimpulan: Hasil dari representasi pada pemodelan data spasial dan data atribut ini dapat digunakan sebagai rujukan untuk melakukan perencanaan dalam pengembangan pusat layanan kesehatan pada wilayah dengan kategori status imunisasi buruk.
\end{abstract}

Kata Kunci: analisa spasial, pemodelan data spasial, penyakit campak, MADM. 


\section{Pendahuluan}

Campak adalah penyebab angka kematian terbesar di dunia, World Health Organization (WHO) mencatat bahwa Indonesia berada di peringkat ke-5 untuk penyebaran penyakit campak dan rubella secara global (World Health Organization, 2017) diperbarui pada Juni 2018. Pemerintah dalam hal ini Dinas Kesehatan, saat menentukan wilayah kejadian luar biasa (KLB) terhadap daerah rawan penyakit campak pada suatu wilayah berdasarkan faktor angka kejadian kasus yang dibukukan dalam Buku Profil Kesehatan. Data penyakit campak di Provinsi Jawa Timur, disajikan dalam bentuk peta analog dan buku profil kesehatan Provinsi Jawa Timur yang terdokumentasi pada setiap tahunnya. Data tersebut dapat digunakan untuk menggambarkan cakupan data dasar sebagai informasi awal data penyakit campak dan ruang lingkup analisis data. Ruang lingkup data analisis berdasarkan parameter yang mempengaruhi terjadinya kejadian luar biasa (endemik) memberikan klasifikasi daerah rawan penyakit tropis campak berdasarkan faktor risiko status imunisasi melalui analisis dalam pemodelan data spasial.

Representasi hasil pemodelan data spasial dilakukan dengan menguraikan kebutuhan data dasar (peta analog dan data tabular), sedangkan analisa spasial dengan menguraikan metode AI yang digunakan untuk proses pemodelan data spasial (T.C. Bailey, 1995) (Parker \& Asencio, 2009) (Banerjee, Carlin, \& Gelfand, 2014) (Patanè \& Spagnuolo, 2016). Data tabular merupakan data kualitatif dalam bentuk angka yang diperoleh dari hasil perhitungan dan pengukuran (A. S. Fotheringham, C. Brundson, 2010).

Penelitian sebelumnya membahas framework melalui analisis dan desain sistem informasi geografis (SIG) berbasis web yang dimulai dengan menganalisis persyaratan sistem informasi, analisa geoprosesing layer, dan membuat prototipe sistem, disini masih merupakan framework global untuk semua penyakit tropis yang meliputi tuberculosis (TBC), difteri, pertusis, tetanus neonatorum, kusta, demam berdarah dengue (DBD), campak, HIV-AIDS, malaria, dan filariasis) (A. V. Vitianingsih, Cahyono, \& Choiron, 2017). Analisa pada spasial data modeling untuk penyakit campak dengan menggunakan metode AI Simple Additive Weighting (SAW) didapatkan hasil uji konsistensi dengan metode Cohen's Kappa Method Consistency Test (MCT) memiliki nilai koefisien moderate dengan rata-rata nilai $K=0,41$ (A. Vitianingsih, Choiron, Cahyono, Umam, \& Suyanto, 2019). Metode SAW dipilih pada analisa pemodelan data spasial karena perilaku data kualitatif diperoleh, sehingga akan memudahkan komputasi untuk memberikan efisiensi, memiliki kemampuan untuk mengukur kriteria parameter, dan menghasilkan alternatif pengambilan keputusan dalam bentuk matematika sederhana. Tetapi, pada penelitian tersebut belum ditampilkan representasi hasil keseluruan nilai persentase wilayah dengan kategori baik, cukup, kurang, dan buruk per tahunnya. Cara melakukan identifikasi pada parameter yang mempengaruhi kejadian suatu penyakit, seperti halnya penyakit campak sudah dimodelkan secara matematis (Hadeler, 2011). Identifikasi parameter dengan model nonspasial, output yang dihasilkan meliputi data seri waktu prevalensi, populasi dari penyebaran penyakit dan kondisi dinamika lingkungan (Almberg, Cross, Johnson, Heisey, \& Richards, 2011).

Pembahasan pada paper ini mengusulkan akuisisi data berupa representasi hasil analisa pada proses pemodelan data spasial melalui Buku Profil Kesehatan Provinsi Jawa Timur dari tahun 20112016 menggunakan metode SAW, dengan menampilkan persentase wilayah rawan penyakit campak per kabupaten berdasarkan parameter imunisasi bayi, penyakit yang dapat dicegah dengan imunisasi (PD3I), kejadian luar biasa campak (epidemi) dan status gizi (Ingridara \& Garna, 2017). Data tersebut menjadi data kualitatif yang terdiri dari kriteria multiparameter untuk sistem pengambilan keputusan (MADM).

Hasil representasi analisa pada pemodelan data spasial penyakit campak ini yaitu peta dasar regional dalam bentuk shapefile (*.shp) digital dan analisis peta dalam bentuk dataset spasial yang digunakan sebagai parameter yang mempengaruhi suatu wilayah dikatakan rentan terhadap sebaran penyakit campak. Persentase hasil pemodelan data spasial dengan metode SAW dalam bentuk klasifikasi cakupan status imunisasi penyakit campak, yaitu (i) baik, jika tren bulan sekarang naik dibandingkan bulan lalu dan nilai kumulatif hingga bulan berjalan tercapai atau melampaui target, (ii)

To cite this document:

Vitianingsih, A. V, Choiron, A., Cahyono, D., \& Suyanto. (2020). Representation of Spatial Data Modeling Results

Measles Diseases: Case Study in East Java Province. Record and Library Journal, 6(1), 14-23.

Open access under Creative Commons Attribution-Share A like 4.0 International Licence 
cukup, jika tren bulan sekarang naik dibandingkan bulan lalu dan nilai kumulatif hingga bulan berjalan mencapai target minimum, (iii) kurang, jika tren bulan sekarang naik dibandingkan bulan lalu dan nilai kumulatifnya sampai bulan berjalan tidak mencapai minimum, dan (iv) buruk, jika tren turun dibandingkan bulan lalu dan nilai kumulatif hingga bulan berjalan tidak tercapai / tidak melebihi target. Hasil ini dapat digunakan sebagai referensi dalam mengembangkan pemodelan data spasial, untuk memetakan daerah tropis yang terkena penyakit campak berdasarkan klasifikasi cakupan status imunisasi sebagai langkah mitigasi untuk mengatasi dan mengantisipasi penyebaran penyakit campak. Penggunaan teknologi GIS untuk memetakan pengawasan penyakit campak sebagai langkah mitigasi sudah banyak dilakukan pada banyak negara(N. Bhart, A. Djibo, M. J. Ferrari, R. F.Grais, A. J. Tatem, C. A. Mccabe, O. N. Bjornstad, 2010) termasuk diantaranya negara Cina, (Y. Zhu et al., 2013) (B. Zhu, Fu, Liu, \& Mao, 2018) (Gao, 2010), Thailand (Laohasiriwong, Puttanapong, \& Singsalasang, 2018), Istanbul (Ulugtekin, Alkoy, Seker, \& Goksel, 2006), dan Ireland (Fitzpatrick et al., 2012).

\section{Metode Penelitian}

Metode penelitian pada Gambar 1 menjabarkan urutan langkah-langkah untuk menampilkan representasi hasil pemodelan data spasial penyakit campak. Langkah pertama yang harus dilakukan adalah dengan melakukan analisa kebutuhan data dasar berupa peta analog Provinsi Jawa Timur yang berisi kecamatan pada masing kabupaten, dan data tabular penyakit campak yang didapatkan dari Buku Profil Kesehatan (Dinas Kesehatan Provinsi Jawa Timur, 2012) (Dinas Kesehatan Provinsi Jawa Timur, 2013) (Timur, 2014) (Dinas Kesehatan Provinsi Jawa Timur, 2015a) (Dinas Kesehatan Provinsi Jawa Timur, 2015b) (Dinas Kesehatan Provinsi Jawa Timur, 2017). Peta analog digunakan sebagai bahan untuk mendapatkan layer peta digital (*.shp) sebagai data spasial dengan melakukan digitasi.

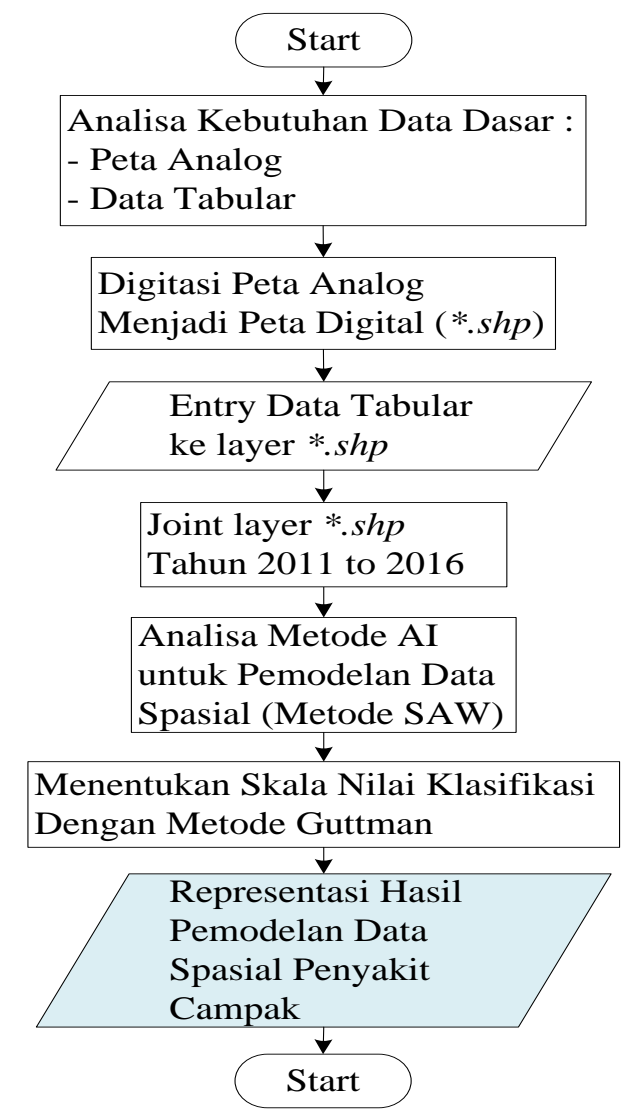

Grafik 1. Metode Penelitian Representasi Hasil Pemodelan Data Spasial Penyakit Campak

To cite this document:

Vitianingsih, A. V, Choiron, A., Cahyono, D., \& Suyanto. (2020). Representation of Spatial Data Modeling Results

Measles Diseases: Case Study in East Java Province. Record and Library Journal, 6(1), 14-23.

Open access under Creative Commons Attribution-Share A like 4.0 International Licence 
Data tabular digunakan sebagai dasar data yang akan digunakan untuk menganalisa kebutuhan parameter sebagai data atribut. Entry Data tabular ke layer (*.shp) pada masing-masing kecamatan ditiap kabupaten dengan menggabungkan semua hasil layer dari tahun 2011 sampai tahun 2016. Melakukan analisa metode AI yang digunakan dalam pemodelan data spasial dengan metode SAW berdasarkan parameter imunisasi bayi, PD3I, KLB, dan status gizi (A. Vitianingsih et al., 2019). Bobot atribut dan tingkat kepentingan di setiap parameter diperoleh dari sumber wawancara di Divisi Pengendalian dan Pencegahan Penyakit untuk Divisi Pengawasan dan Imunisasi Dinas Kesehatan Provinsi Jawa Timur. Nilai preverensi untuk menentukan range nilai pada skala klasifikasi yang dihitung dengan metode Guttman (Guttman, 1944), nilai variabel $V_{i}$ pada perhitungan metode SAW diperoleh dari hasil normalisasi dan preferensi pada setiap atribut parameter dimana (i) wilayah dengan cakupan imunisasi baik jika nilai $V_{i} \geq 0,875$, (ii) wilayah dengan cakupan imunisasi baik jika nilai cukup $V_{i} \geq 0,75 \& \& V_{i}<0,875$, (iii) wilayah dengan cakupan imunisasi baik jika nilai kurang $V_{i} \geq 0,625 \& \& V_{i}<0,75$, dan (iv) wilayah dengan cakupan imunisasi baik jika nilai buruk $V_{i}<0,625$ (A. Vitianingsih et al., 2019). Nilai tersebut akan menghasilkan representasi persentase wilayah dengan kategori cakupan status imunisasi baik, cukup, kurang, dan buruk.

\section{Hasil dan Diskusi}

Representasi Hasil pemodelan data spasial pada penyakit campak tahun 2011-2016 dengan metode SAW berdasarkan parameter status imunisasi bayi, PD3I, epidemik, dan status gizi bayi pada Gambar 2. Kecamatan yang terdapat pada masing-masing kabupaten diberikan visualisasi dalam bentuk peta digital. Kecamatan dengan warna hijau merupakan wilayah dengan status cakupan imunisasi baik, termasuk wilayah dengan kategori tidak rawan untuk penyebaran penyakit campak. Warna orange menggambarkan wilayah dengan status cakupan imunisasi cukup, sehingga perlu diwaspadai untuk penyebaran penyakit campak. Warna orange dan merah termasuk wilayah dengan status imunisasi kurang dan buruk, sehingga hal ini harus ada tindakan pencegahan sebagai upaya antisipasi wilayah rawan penyebaran penyakit campak.

Representasi hasil pemodelan data atribut yang dihasilkan pada proses pemodelan data spasial pada Tabel 1, dan Tabel 2 merupakan nilai persentase kenaikan atau penurunan nilai yang disinkronkan dengan data KLB di lapangan. Data tersebut hasil dari per kabupaten yang direkap dari total kecamatan yang termasuk wilayah rawan penyakit tropis campak dengan cakupan status imunisasi baik, cukup, kurang, dan buruk. Uji coba wilayah sudah dilakukan pada Kabupaten Ngambon Kecamatan Bojonegoro (A. Vitianingsih et al., 2019), di mana hasil perhitungan manual dengan hasil uji coba pada pemodelan data spasial sudah sesuai nilai kebenarannya.

To cite this document:

Vitianingsih, A. V, Choiron, A., Cahyono, D., \& Suyanto. (2020). Representation of Spatial Data Modeling Results

Measles Diseases: Case Study in East Java Province. Record and Library Journal, 6(1), 14-23.

Open access under Creative Commons Attribution-Share A like 4.0 International Licence 


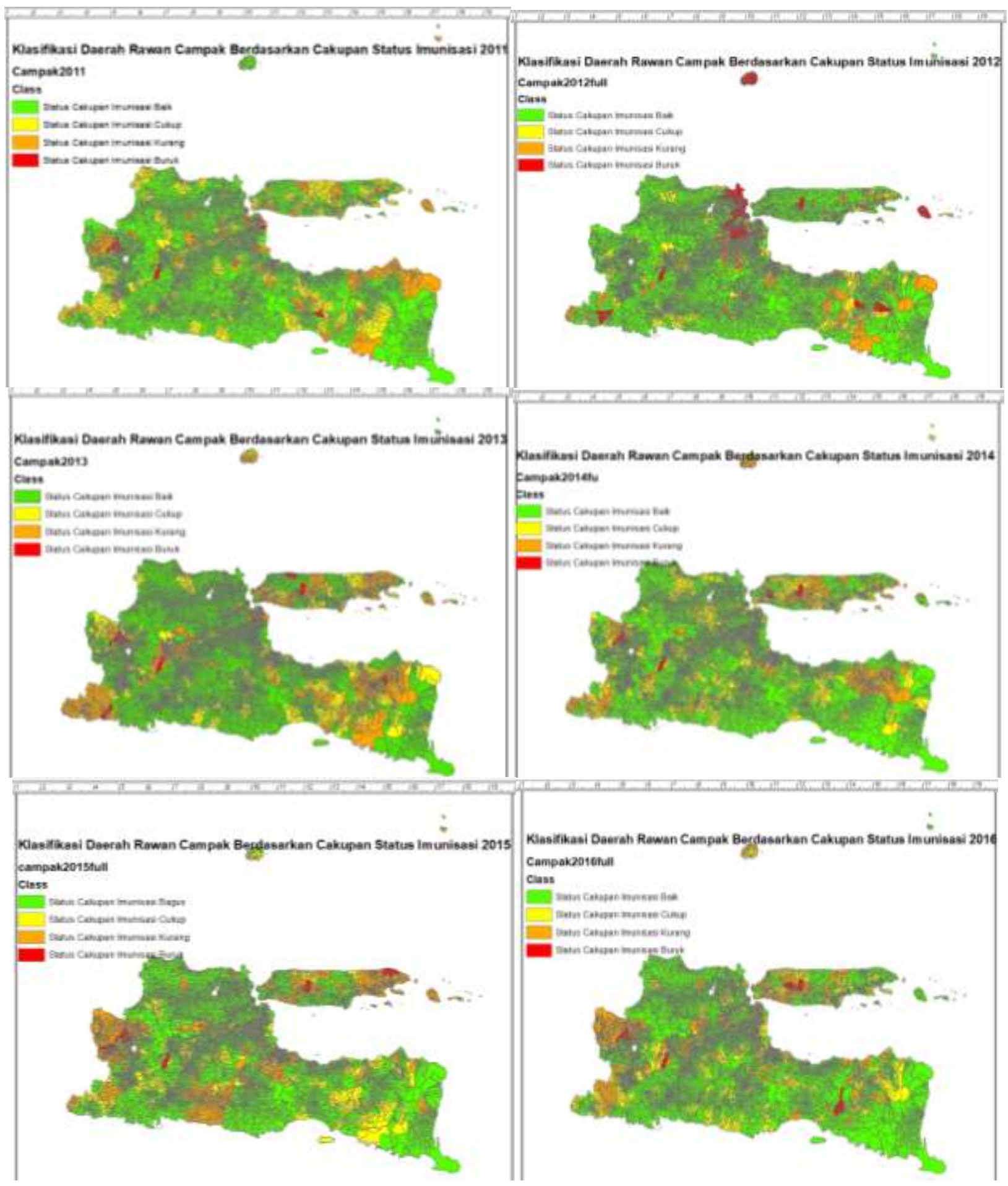

Gambar 2. Hasil Pemodelan Data Spasial Penyakit CampakProsentase Daerah Rawan Penyakit Tropis berdasarkan Cakupan Status Imunisasi

Tabel 1. Total Wilayah Dengan Hasil Klasifikasi Metode SAW

\begin{tabular}{lllllll}
\hline Class & 2011 & 2012 & 2013 & 2014 & 2015 & 2016 \\
\hline Baik & $69 \%$ & $74 \%$ & $64 \%$ & $67 \%$ & $62 \%$ & $66 \%$ \\
Cukup & $17 \%$ & $12 \%$ & $14 \%$ & $20 \%$ & $16 \%$ & $20 \%$
\end{tabular}

To cite this document:

Vitianingsih, A. V, Choiron, A., Cahyono, D., \& Suyanto. (2020). Representation of Spatial Data Modeling Results Measles Diseases: Case Study in East Java Province. Record and Library Journal, 6(1), 14-23.

Open access under Creative Commons Attribution-Share A like 4.0 International Licence 


\begin{tabular}{lcccccc} 
Kurang & $12 \%$ & $9 \%$ & $18 \%$ & $11 \%$ & $19 \%$ & $12 \%$ \\
Buruk & $2 \%$ & $5 \%$ & $4 \%$ & $2 \%$ & $2 \%$ & $2 \%$ \\
\hline
\end{tabular}

Tabel 2. Representasi hasil pemodelan data spasial Untuk Prosentase Daerah Rawan Penyakit Tropis berdasarkan Cakupan Status Imunisasi Dengan Metode SAW Tahun 2011-2016

\begin{tabular}{|c|c|c|c|c|c|c|c|c|c|c|c|c|c|c|c|}
\hline \multirow{2}{*}{ District } & \multicolumn{4}{|c|}{2011} & \multicolumn{4}{|c|}{2012} & \multicolumn{7}{|c|}{2013} \\
\hline & Baik & Cukup & Kurang & Buruk & Baik & Cukup & Kurang & Buruk & \multicolumn{2}{|c|}{ Baik } & \multicolumn{2}{|c|}{ Cukup } & \multicolumn{2}{|c|}{ Kurang } & Buruk \\
\hline Pacitan & $7,69 \%$ & $84,62 \%$ & $0,00 \%$ & $7,69 \%$ & $28,57 \%$ & $42,85 \%$ & $21,42 \%$ & $7,14 \%$ & \multicolumn{2}{|c|}{$0,00 \%$} & \multicolumn{2}{|c|}{$7,69 \%$} & \multicolumn{2}{|c|}{$0,00 \%$} & $92,31 \%$ \\
\hline Ponorogo & $10,00 \%$ & $70,00 \%$ & $20,00 \%$ & $0,00 \%$ & $5,00 \%$ & $65,00 \%$ & $30,00 \%$ & $0,00 \%$ & \multicolumn{2}{|c|}{$5,00 \%$} & \multicolumn{2}{|c|}{$45,00 \%$} & \multicolumn{2}{|c|}{$50,00 \%$} & $0,00 \%$ \\
\hline Ternggalek & $7,14 \%$ & $42,86 \%$ & $50,00 \%$ & $0,00 \%$ & $7,69 \%$ & $38,46 \%$ & $53,85 \%$ & $0,00 \%$ & \multicolumn{2}{|c|}{$\begin{array}{r}15,38 \\
\%\end{array}$} & \multicolumn{2}{|c|}{$38,46 \%$} & \multicolumn{2}{|c|}{$46,15 \%$} & $0,00 \%$ \\
\hline Tulungaguang & $5,26 \%$ & $73,68 \%$ & $21,05 \%$ & $0,00 \%$ & $5,26 \%$ & $26,32 \%$ & $68,42 \%$ & $0,00 \%$ & 5,2 & & & $32 \%$ & & $2 \%$ & $0,00 \%$ \\
\hline Blitar & $12,00 \%$ & $72,00 \%$ & $16,00 \%$ & $0,00 \%$ & $4,17 \%$ & $87,50 \%$ & $8,33 \%$ & $0,00 \%$ & 8,3 & & & $0 \%$ & & $7 \%$ & $0,00 \%$ \\
\hline Kediri & $6,90 \%$ & $75,86 \%$ & $17,24 \%$ & $0,00 \%$ & $8,00 \%$ & $72,00 \%$ & $20,00 \%$ & $0,00 \%$ & 8,0 & & & $00 \%$ & & $0 \%$ & $0,00 \%$ \\
\hline Malang & $2,63 \%$ & $47,37 \%$ & $50,00 \%$ & $0,00 \%$ & $0,00 \%$ & $72,97 \%$ & $27,03 \%$ & $0,00 \%$ & 5,4 & & & $5 \%$ & & $4 \%$ & $0,00 \%$ \\
\hline Lumajang & $9,52 \%$ & $47,62 \%$ & $42,86 \%$ & $0,00 \%$ & $0,00 \%$ & $36,84 \%$ & $63,16 \%$ & $0,00 \%$ & 5,2 & & & $37 \%$ & & $7 \%$ & $0,00 \%$ \\
\hline Jember & $6,45 \%$ & $67,74 \%$ & $25,81 \%$ & $0,00 \%$ & $3,23 \%$ & $41,94 \%$ & $54,84 \%$ & $0,00 \%$ & 6,4 & & & $51 \%$ & & $1 \%$ & $3,23 \%$ \\
\hline Banyuangi & $0,00 \%$ & $41,67 \%$ & $58,33 \%$ & $0,00 \%$ & $4,17 \%$ & $58,33 \%$ & $37,50 \%$ & $0,00 \%$ & 0,0 & & & $00 \%$ & & $0 \%$ & $0,00 \%$ \\
\hline Bondowoso & $4,17 \%$ & $20,83 \%$ & $70,83 \%$ & $4,17 \%$ & $8,33 \%$ & $37,50 \%$ & $50,00 \%$ & $4,17 \%$ & 0,0 & & & $00 \%$ & & $7 \%$ & $70,83 \%$ \\
\hline Situbondo & $0,00 \%$ & $0,00 \%$ & $0,00 \%$ & $100,00 \%$ & $23,53 \%$ & $58,82 \%$ & $17,65 \%$ & $0,00 \%$ & 5,8 & & & $59 \%$ & & $3 \%$ & $0,00 \%$ \\
\hline Probolinggo & $11,11 \%$ & $59,26 \%$ & $29,63 \%$ & $0,00 \%$ & $7,41 \%$ & $77,78 \%$ & $14,81 \%$ & $0,00 \%$ & 3,7 & & & $57 \%$ & & $3 \%$ & $0,00 \%$ \\
\hline Pasuruan & $10,34 \%$ & $3,45 \%$ & $79,31 \%$ & $6,90 \%$ & $0,00 \%$ & $17,24 \%$ & $75,86 \%$ & $6,90 \%$ & 0,0 & & & $00 \%$ & & $5 \%$ & $89,66 \%$ \\
\hline Sidoarjo & $5,56 \%$ & $33,33 \%$ & $61,11 \%$ & $0,00 \%$ & $16,67 \%$ & $33,33 \%$ & $50,00 \%$ & $0,00 \%$ & 5,5 & & & $00 \%$ & & $4 \%$ & $0,00 \%$ \\
\hline Mojokerto & $5,00 \%$ & $55,00 \%$ & $40,00 \%$ & $0,00 \%$ & $0,00 \%$ & $10,00 \%$ & $15,00 \%$ & $75,00 \%$ & 5,0 & & & $00 \%$ & & $0 \%$ & $5,00 \%$ \\
\hline Jombang & $4,76 \%$ & $71,43 \%$ & $23,81 \%$ & $0,00 \%$ & 9,52 & $57,14 \%$ & $33,33 \%$ & $0,00 \%$ & 14,2 & & & $19 \%$ & & $2 \%$ & $0,00 \%$ \\
\hline Nganjuk & $0,00 \%$ & $4,76 \%$ & $38,10 \%$ & $57,14 \%$ & $0,00 \%$ & $4,76 \%$ & $23,81 \%$ & $71,43 \%$ & 0,0 & & & $76 \%$ & & $2 \%$ & $85,71 \%$ \\
\hline Madiun & $0,00 \%$ & $40,00 \%$ & $60,00 \%$ & $0,00 \%$ & $13,33 \%$ & $20,00 \%$ & $66,67 \%$ & $0,00 \%$ & 6,6 & & & $33 \%$ & & $0 \%$ & $0,00 \%$ \\
\hline Magetan & $20,00 \%$ & $65,00 \%$ & $5,00 \%$ & $10,00 \%$ & $5,00 \%$ & $75,00 \%$ & $10,00 \%$ & $10,00 \%$ & 10,0 & & & $0 \%$ & & $0 \%$ & $10,00 \%$ \\
\hline Ngawi & $0,00 \%$ & $30,00 \%$ & $60,00 \%$ & $10,00 \%$ & $0,00 \%$ & $30,00 \%$ & $65,00 \%$ & $5,00 \%$ & 15,0 & & & $00 \%$ & & $0 \%$ & $5,00 \%$ \\
\hline Tuban & $10,00 \%$ & $75,00 \%$ & $15,00 \%$ & $0,00 \%$ & $5,00 \%$ & $70,00 \%$ & $25,00 \%$ & $0,00 \%$ & 5,0 & & & $00 \%$ & & $0 \%$ & $0,00 \%$ \\
\hline Lamongan & $3,70 \%$ & $22,22 \%$ & $74,07 \%$ & $0,00 \%$ & $3,70 \%$ & $62,96 \%$ & $33,33 \%$ & $0,00 \%$ & 0,0 & & & $41 \%$ & & $9 \%$ & $0,00 \%$ \\
\hline Bojonegoro & - & - & - & - & $10,71 \%$ & $46,43 \%$ & $39,29 \%$ & $3,57 \%$ & 7,1 & & & $00 \%$ & & $9 \%$ & $3,57 \%$ \\
\hline Gresik & $11,11 \%$ & $11,11 \%$ & $77,78 \%$ & $0,00 \%$ & $0,00 \%$ & $0,00 \%$ & $0,00 \%$ & $\begin{array}{r}100,00 \\
\%\end{array}$ & 0,0 & & & $56 \%$ & & $4 \%$ & $0,00 \%$ \\
\hline Bangkalan & $0,00 \%$ & $72,22 \%$ & $27,78 \%$ & $0,00 \%$ & $0,00 \%$ & $72,22 \%$ & $27,78 \%$ & $0,00 \%$ & 0,0 & & & $33 \%$ & & $9 \%$ & $27,78 \%$ \\
\hline Sampang & $14,29 \%$ & $14,29 \%$ & $71,43 \%$ & $0,00 \%$ & $0,00 \%$ & $42,86 \%$ & $50,00 \%$ & $7,14 \%$ & 7,1 & & & $14 \%$ & & $7 \%$ & $7,14 \%$ \\
\hline Pamekasan & $15,38 \%$ & $76,92 \%$ & $7,69 \%$ & $0,00 \%$ & $23,08 \%$ & $53,85 \%$ & $23,08 \%$ & $0,00 \%$ & 0,0 & & & $15 \%$ & & $5 \%$ & $0,00 \%$ \\
\hline Sumenep & $3,57 \%$ & $25,00 \%$ & $67,86 \%$ & $3,57 \%$ & $0,00 \%$ & $28,57 \%$ & $67,86 \%$ & $3,57 \%$ & 0,0 & & & $14 \%$ & & $6 \%$ & $75,00 \%$ \\
\hline Surabaya & $0,00 \%$ & $22,58 \%$ & $67,74 \%$ & $9,68 \%$ & $6,45 \%$ & $16,13 \%$ & $77,42 \%$ & $0,00 \%$ & 3,2 & & & $58 \%$ & & $9 \%$ & $0,00 \%$ \\
\hline Batu & $66,67 \%$ & $33,33 \%$ & $0,00 \%$ & $0,00 \%$ & $66,67 \%$ & $33,33 \%$ & $0,00 \%$ & $0,00 \%$ & 33,3 & & & $57 \%$ & & $0 \%$ & $0,00 \%$ \\
\hline & & & 014 & & & & 2015 & & & & & & & & \\
\hline & Baik & Cukup & Kurang & Buruk & Baik & Cukup & Kurang & & & & & & & Kurang & Buruk \\
\hline Pacitan & $7,69 \%$ & $53,85 \%$ & $30,77 \%$ & $7,69 \%$ & $7,69 \%$ & $53,85 \%$ & $30,77 \%$ & & $69 \%$ & & & & & $23,08 \%$ & $7,69 \%$ \\
\hline Ponorogo & $5,00 \%$ & $75,00 \%$ & $20,00 \%$ & $0,00 \%$ & $10,00 \%$ & $30,00 \%$ & $60,00 \%$ & & $00 \%$ & & & & & $35,00 \%$ & $0,00 \%$ \\
\hline Ternggalek & $7,69 \%$ & $38,46 \%$ & $53,85 \%$ & $0,00 \%$ & $7,69 \%$ & $46,15 \%$ & $46,15 \%$ & & $00 \%$ & & & & & $30,77 \%$ & $0,00 \%$ \\
\hline Tulungaguang & $5,26 \%$ & $42,11 \%$ & $52,63 \%$ & $0,00 \%$ & $5,26 \%$ & $36,84 \%$ & $57,89 \%$ & & $00 \%$ & & & 47, & & $47,37 \%$ & $0,00 \%$ \\
\hline Blitar & $0,00 \%$ & $70,83 \%$ & $29,17 \%$ & $0,00 \%$ & $0,00 \%$ & $12,50 \%$ & $0,00 \%$ & & $50 \%$ & 12 & & & & $79,17 \%$ & $0,00 \%$ \\
\hline Kediri & $8,00 \%$ & $44,00 \%$ & $48,00 \%$ & $0,00 \%$ & $4,00 \%$ & $84,00 \%$ & $12,00 \%$ & & $00 \%$ & & & 80 , & & $12,00 \%$ & $0,00 \%$ \\
\hline
\end{tabular}

To cite this document:

Vitianingsih, A. V, Choiron, A., Cahyono, D., \& Suyanto. (2020). Representation of Spatial Data Modeling Results

Measles Diseases: Case Study in East Java Province. Record and Library Journal, 6(1), 14-23.

Open access under Creative Commons Attribution-Share A like 4.0 International Licence 


\begin{tabular}{|c|c|c|c|c|c|c|c|c|c|c|c|c|}
\hline \multirow{3}{*}{$\begin{array}{c}\text { District } \\
\text { Malang }\end{array}$} & \multicolumn{4}{|c|}{2011} & \multicolumn{4}{|c|}{2012} & \multicolumn{4}{|c|}{2013} \\
\hline & \multirow{2}{*}{$\begin{array}{r}\text { Baik } \\
0,00 \%\end{array}$} & \multirow{2}{*}{$\begin{array}{l}\text { Cukup } \\
35,14 \%\end{array}$} & \multirow{2}{*}{$\begin{array}{r}\text { Kurang } \\
64,86 \%\end{array}$} & \multirow{2}{*}{$\begin{array}{l}\text { Buruk } \\
0,00 \%\end{array}$} & \multirow{2}{*}{$\begin{array}{l}\text { Baik } \\
5,41 \%\end{array}$} & \multirow{2}{*}{$\begin{array}{l}\text { Cukup } \\
51,35 \%\end{array}$} & \multirow{2}{*}{$\begin{array}{r}\text { Kurang } \\
43,24 \%\end{array}$} & Buruk & Baik & Cukup & Kurang & Buruk \\
\hline & & & & & & & & $0,00 \%$ & $8,11 \%$ & $72,97 \%$ & $18,92 \%$ & $0,00 \%$ \\
\hline Lumajang & $5,26 \%$ & $36,84 \%$ & $52,63 \%$ & $5,26 \%$ & $5,26 \%$ & $26,32 \%$ & $68,42 \%$ & $0,00 \%$ & $5,26 \%$ & $63,16 \%$ & $31,58 \%$ & $0,00 \%$ \\
\hline Jember & $3,23 \%$ & $48,39 \%$ & $45,16 \%$ & $3,23 \%$ & $6,45 \%$ & $64,52 \%$ & $29,03 \%$ & $0,00 \%$ & $6,45 \%$ & $74,19 \%$ & $19,35 \%$ & $0,00 \%$ \\
\hline Banyuangi & $0,00 \%$ & $50,00 \%$ & $50,00 \%$ & $0,00 \%$ & $0,00 \%$ & $33,33 \%$ & $62,50 \%$ & $4,17 \%$ & $4,17 \%$ & $20,83 \%$ & $75,00 \%$ & $0,00 \%$ \\
\hline Bondowoso & $0,00 \%$ & $25,00 \%$ & $70,83 \%$ & $4,17 \%$ & $4,17 \%$ & $41,67 \%$ & $50,00 \%$ & $4,17 \%$ & $4,17 \%$ & $33,33 \%$ & $58,33 \%$ & $4,17 \%$ \\
\hline Situbondo & $17,65 \%$ & $47,06 \%$ & $35,29 \%$ & $0,00 \%$ & $11,76 \%$ & $41,18 \%$ & $47,06 \%$ & $0,00 \%$ & $5,88 \%$ & $58,82 \%$ & $35,29 \%$ & $0,00 \%$ \\
\hline Probolinggo & $3,70 \%$ & $62,96 \%$ & $29,63 \%$ & $3,70 \%$ & $3,70 \%$ & $59,26 \%$ & $33,33 \%$ & $3,70 \%$ & $7,41 \%$ & $66,67 \%$ & $25,93 \%$ & $0,00 \%$ \\
\hline Pasuruan & $0,00 \%$ & $10,34 \%$ & $20,69 \%$ & $68,97 \%$ & $0,00 \%$ & $10,34 \%$ & $79,31 \%$ & $10,34 \%$ & $0,00 \%$ & $6,90 \%$ & $82,76 \%$ & $10,34 \%$ \\
\hline Sidoarjo & $5,56 \%$ & $55,56 \%$ & $38,89 \%$ & $0,00 \%$ & $22,22 \%$ & $72,22 \%$ & $5,56 \%$ & $0,00 \%$ & b $\quad 16,67 \%$ & $61,11 \%$ & $22,22 \%$ & $0,00 \%$ \\
\hline Mojokerto & $0,00 \%$ & $75,00 \%$ & $25,00 \%$ & $0,00 \%$ & $0,00 \%$ & $20,00 \%$ & $80,00 \%$ & $0,00 \%$ & $5,00 \%$ & $50,00 \%$ & $45,00 \%$ & $0,00 \%$ \\
\hline Jombang & $23,81 \%$ & $66,67 \%$ & $9,52 \%$ & $0,00 \%$ & $0,00 \%$ & $23,81 \%$ & $76,19 \%$ & $0,00 \%$ & $4,76 \%$ & $28,57 \%$ & $66,67 \%$ & $0,00 \%$ \\
\hline Nganjuk & $0,00 \%$ & $9,52 \%$ & $85,71 \%$ & $4,76 \%$ & $4,76 \%$ & $38,10 \%$ & $52,38 \%$ & $4,76 \%$ & $0,00 \%$ & $9,52 \%$ & $38,10 \%$ & $52,38 \%$ \\
\hline Madiun & $0,00 \%$ & $93,33 \%$ & $6,67 \%$ & $0,00 \%$ & $6,67 \%$ & $40,00 \%$ & $53,33 \%$ & $0,00 \%$ & $6,67 \%$ & $60,00 \%$ & $33,33 \%$ & $0,00 \%$ \\
\hline Magetan & $20,00 \%$ & $55,00 \%$ & $15,00 \%$ & $10,00 \%$ & $0,00 \%$ & $5,00 \%$ & $35,00 \%$ & $60,00 \%$ & $5,00 \%$ & $70,00 \%$ & $15,00 \%$ & $10,00 \%$ \\
\hline Ngawi & $5,00 \%$ & $50,00 \%$ & $40,00 \%$ & $5,00 \%$ & $0,00 \%$ & $0,00 \%$ & $15,00 \%$ & $85,00 \%$ & $5,00 \%$ & $25,00 \%$ & $60,00 \%$ & $10,00 \%$ \\
\hline Tuban & $5,00 \%$ & $60,00 \%$ & $35,00 \%$ & $0,00 \%$ & $10,00 \%$ & $65,00 \%$ & $25,00 \%$ & $0,00 \%$ & $0,00 \%$ & $75,00 \%$ & $25,00 \%$ & $0,00 \%$ \\
\hline Lamongan & $3,70 \%$ & $44,44 \%$ & $51,85 \%$ & $0,00 \%$ & $3,70 \%$ & $51,85 \%$ & $44,44 \%$ & $0,00 \%$ & $3,70 \%$ & $44,44 \%$ & $51,85 \%$ & $0,00 \%$ \\
\hline Bojonegoro & $0,00 \%$ & $50,00 \%$ & $50,00 \%$ & $0,00 \%$ & $7,14 \%$ & $53,57 \%$ & $39,29 \%$ & $0,00 \%$ & $3,57 \%$ & $53,57 \%$ & $42,86 \%$ & $0,00 \%$ \\
\hline Gresik & $5,56 \%$ & $16,67 \%$ & $77,78 \%$ & $0,00 \%$ & $5,56 \%$ & $44,44 \%$ & $50,00 \%$ & $0,00 \%$ & $5,56 \%$ & $22,22 \%$ & $72,22 \%$ & $0,00 \%$ \\
\hline Bangkalan & $5,56 \%$ & $61,11 \%$ & $33,33 \%$ & $0,00 \%$ & $5,56 \%$ & $27,78 \%$ & $61,11 \%$ & $5,56 \%$ & $11,11 \%$ & $38,89 \%$ & $50,00 \%$ & $0,00 \%$ \\
\hline Sampang & $14,29 \%$ & $57,14 \%$ & $21,43 \%$ & $7,14 \%$ & $0,00 \%$ & $78,57 \%$ & $14,29 \%$ & $7,14 \%$ & $7,14 \%$ & $28,57 \%$ & $64,29 \%$ & $0,00 \%$ \\
\hline Pamekasan & $0,00 \%$ & $69,23 \%$ & $30,77 \%$ & $0,00 \%$ & $7,69 \%$ & $38,46 \%$ & $53,85 \%$ & $0,00 \%$ & $7,69 \%$ & $30,77 \%$ & $61,54 \%$ & $0,00 \%$ \\
\hline Sumenep & $7,14 \%$ & $53,57 \%$ & $35,71 \%$ & $3,57 \%$ & $0,00 \%$ & $28,57 \%$ & $67,86 \%$ & $3,57 \%$ & $7,14 \%$ & $50,00 \%$ & $39,29 \%$ & $3,57 \%$ \\
\hline Surabaya & $6,45 \%$ & $29,03 \%$ & $64,52 \%$ & $0,00 \%$ & $6,45 \%$ & $74,19 \%$ & $19,35 \%$ & $0,00 \%$ & $6,45 \%$ & $61,29 \%$ & $29,03 \%$ & $3,23 \%$ \\
\hline Batu & $33,33 \%$ & $66,67 \%$ & $0,00 \%$ & $0,00 \%$ & $33,33 \%$ & $66,67 \%$ & $0,00 \%$ & $0,00 \%$ & $33,33 \%$ & $66,67 \%$ & $0,00 \%$ & $0,00 \%$ \\
\hline
\end{tabular}

\section{Kesimpulan}

Representasi hasil pada pemodelan data spasial ini merupakan langkah konkret untuk merencanakan dan menggambarkan persyaratan data, metode AI dan desain arsitektur aplikasi GIS yang akan dibangun. Kegiatan-kegiatan dalam analisis data spasial yang digunakan sebagai dasar untuk pemodelan data spasial SIG, meliputi (i) menggambarkan kebutuhan data spasial dan data atribut yang akan digunakan sebagai dasar untuk pemodelan data spasial SIG, (ii) membuat pemodelan sistem proses menggunakan use case diagram, (iii) membuat desain arsitektur teknologi informasi untuk mengetahui arah teknologi yang akan dikembangkan, dan (iv) Memilih dan menentukan metode AI yang sesuai dengan perilaku data yang telah dianalisis, ini adalah bagian yang sangat penting karena berkaitan dengan nilai-nilai hasil alternatif yang akan dihasilkan. Studi model MADM dengan metode SAW dalam pembahasan makalah ini dapat menjadi referensi dalam pemodelan data spasial dan data atribut untuk membuat aplikasi berbasis desktop atau Web-GIS. Nilai preferensi pada variable $V_{i}$ dalam metode SAW dapat diimplementasikan pada uji coba pemodelan data spasial dalam GIS, menggunakan perilaku data series yang berbeda untuk menentukan validitas hasil klasifikasi alternatif. Penelitian di masa depan yang dapat dilakukan adalah dengan menguji tingkat perbandingan hasil pengukuran di lapangan dengan hasil representasi data yang dihasilkan pada pemodelan data spasial ini melalui perhitungan nilai presisi, recall, dan akurasi.

To cite this document:

Vitianingsih, A. V, Choiron, A., Cahyono, D., \& Suyanto. (2020). Representation of Spatial Data Modeling Results

Measles Diseases: Case Study in East Java Province. Record and Library Journal, 6(1), 14-23.

Open access under Creative Commons Attribution-Share A like 4.0 International Licence 


\section{Ucapan Terima Kasih}

Makalah ini adalah hasil dari kegiatan tahun kedua pada Penelitian Strategis Nasional yang didanai oleh Direktorat Penelitian dan Pengabdian kepada Masyarakat. Direktorat Jenderal Penguatan Penelitian dan Pengembangan Kementerian Riset, Teknologi, dan Pendidikan Tinggi sesuai dengan Kontrak Penelitian Tahun Anggaran 2018 Nomor: 120 / SP2H / LT / DRPM / 2018, 30 Januari 2018. Terima kasih kepada Dinas Kesehatan Provinsi Jawa Timur untuk data "Buku Profil Kesehatan Provinsi Jawa Timur 2011-2016" yang diberikan untuk pengujian metode yang digunakan.

\section{Referensi}

A. S. Fotheringham, C. Brundson, and M. C. (2010). Qualitative Geography : Perspectives on Spatial Data Analysis. In The Sage handbook of qualitative geography. https://doi.org/10.1111/j.1467-9787.2009.00642.x

Almberg, E. S., Cross, P. C., Johnson, C. J., Heisey, D. M., \& Richards, B. J. (2011). Modeling routes of chronic wasting disease transmission: Environmental prion persistence promotes deer population decline and extinction. PLoS ONE, 6(5). https://doi.org/10.1371/journal.pone.0019896

Banerjee, S., Carlin, B. P., \& Gelfand, A. E. (2014). Hierarchical Modeling and Analysis for Spatial Data. https://doi.org/10.1007/s11004-006-9076-2

Dinas Kesehatan Provinsi Jawa Timur. (2012). Profil Kesehatan Provinsi Jawa Timur Th 2011. https://doi.org/10.1007/s13398-014-0173-7.2

Dinas Kesehatan Provinsi Jawa Timur. (2013). Profil Kesehatan Provinsi Jawa Timur Tahun 2012. Dinas Kesehatan Provinsi Jawa Timur.

Dinas Kesehatan Provinsi Jawa Timur. (2015a). Profil Kesehatan Provinsi Jawa Timur 2014. Retrieved

from www.depkes.go.id/resources/download/profil/PROFIL_KES...2014/15_Jatim_2014.pdf

Dinas Kesehatan Provinsi Jawa Timur. (2015b). Profil Kesehatan Provinsi Jawa Timur 2015. Dinas Kesehatan Provinsi Jawa Timur.

Dinas Kesehatan Provinsi Jawa Timur. (2017). Profil Kesehatan Provinsi Jawa Timur Tahun 2016. In Profil Kesehatan Provinsi Jawa Timur Tahun 2012. Retrieved from http://www.depkes.go.id/resources/download/profil/PROFIL_KES_PROVINSI_2016/15_Ja tim_2016.pdf

Fitzpatrick, G., Ward, M., Ennis, O., Johnson, H., Cotter, S., Carr, M. J., ... Fitzgerald, M. (2012). Use of a geographic information system to map cases of measles in real-time during an outbreak in Dublin, Ireland, 2011. Eurosurveillance, 17(49), 1-11. https://doi.org/10.2807/ese.17.49.20330-en

Gao, S. (2010). Advanced Health Information Sharing With Web-Based Gis. (272), 272.

Guttman, L. (1944). A Basis for Scaling Qualitative Data. American Sociological Review, 9(2), 139. https://doi.org/10.2307/2086306

Hadeler, K. P. (2011). Parameter identification in epidemic models. Mathematical Biosciences, 229(2), 185-189. https://doi.org/10.1016/j.mbs.2010.12.004

Ingridara, N., \& Garna, H. (2017). Hubungan Usia , Status Gizi , dan Status Imunisasi dengan Kejadian Campak pada Anak Usia 0 - 5 Tahun di Rumah Sakit Umum Daerah Al-Ihsan Periode Januari 2016 - Mei 2017 Relationship Between Age , Nutritional Status , and Immunization Status with the Incid. Bandung Meeting on Global Medicine \& Health (BaMGMH), 1(1), 49-54.

Laohasiriwong, W., Puttanapong, N., \& Singsalasang, A. (2018). Prevalence of hypertension in Thailand: Hotspot clustering detected by spatial analysis. Geospatial Health, 13(1), 20-27. https://doi.org/10.4081/gh.2018.608

N. Bhart, A. Djibo, M. J. Ferrari, R. F.Grais, A. J. Tatem, C. A. Mccabe, O. N. Bjornstad, B. T. G. (2010). Measles hotspots and epidemiological connectivity. Epidemiology and Infection,

To cite this document:

Vitianingsih, A. V, Choiron, A., Cahyono, D., \& Suyanto. (2020). Representation of Spatial Data Modeling Results

Measles Diseases: Case Study in East Java Province. Record and Library Journal, 6(1), 14-23.

Open access under Creative Commons Attribution-Share A like 4.0 International Licence 
138(9), 1308-1316. https://doi.org/10.1017/S0950268809991385

Parker, R. N., \& Asencio, E. K. (2009). GIS and Spatial Analysis for the Social Sciences: Coding, Mapping and Modeling. Political Justice and Religious Values.

Patanè, G., \& Spagnuolo, M. (2016). Heterogenous Spatial Data: Fusion, Modeling, and Analysis for GIS Applications. Synthesis Lectures on Visual Computing, 8(2), 1-155. https://doi.org/10.2200/S00711ED1V01Y201603VCP024

T.C. Bailey, A. C. G. (1995). Interactive Spatial Data Analysis. In Interactive Spatial Data Analysis. https://doi.org/10.1016/0277-9536(95)00183-2

Timur, D. K. P. J. (2014). Profil Kesehatan Provinsi Jawa Timur 2013. Dinas Kesehatan Provinsi Jawa Timur.

Ulugtekin, N., Alkoy, S., Seker, D., \& Goksel, C. (2006). Use of GIS in epidemiology: A case study in Istanbul. Journal of Environmental Science and Health - Part A Toxic/Hazardous Substances and Environmental Engineering, 41(9), 2013-2026. https://doi.org/10.1080/10934520600780636

Vitianingsih, A., Choiron, A., Cahyono, D., Umam, A., \& Suyanto, S. (2019). Spatial Data Modeling on GIS for Classification of Measles-prone Region Using Multiple Attribute Decision Making. International Journal of Intelligent Engineering and Systems, 12(3), 97-107. https://doi.org/10.22266/ijies2019.0630.11

Vitianingsih, A. V., Cahyono, D., \& Choiron, A. (2017). Analysis and design of web-geographic information system for tropical diseases-prone areas: A case study of East Java Province, Indonesia. 2017 4th International Conference on Information Technology, Computer, and Electrical Engineering (ICITACEE), 255-260. https://doi.org/10.1109/ICITACEE.2017.8257713

World Health Organization. (2017). Global Measles and Rubella Update June 2018. World Health Organization, (April), $6 . \quad$ Retrieved from http://www.who.int/immunization/monitoring_surveillance/burden/vpd/surveillance_type/ac tive/Global_MR_Update_February_2018.pdf?ua=1

Zhu, B., Fu, Y., Liu, J., \& Mao, Y. (2018). Spatial distribution of 12 class B notifiable infectious diseases in China: A retrospective study. PLoS ONE, 13(4), 1-17. https://doi.org/10.1371/journal.pone.0195568

Zhu, Y., Xu, Q., Lin, H., Yue, D., Song, L., Wang, C., ... Li, X. (2013). Spatiotemporal analysis of infant measles using population attributable risk in Shandong Province, 1999-2008. PLoS ONE, 8(11). https://doi.org/10.1371/journal.pone.0079334

To cite this document:

Vitianingsih, A. V, Choiron, A., Cahyono, D., \& Suyanto. (2020). Representation of Spatial Data Modeling Results

Measles Diseases: Case Study in East Java Province. Record and Library Journal, 6(1), 14-23.

Open access under Creative Commons Attribution-Share A like 4.0 International Licence 